\title{
Türk Resminin ve Toplum Hayatının Değişim Göstergesi Olarak Kadın*
}

\author{
Yrd. Doç. Dr. Ferhunde Küçükşen Öner
}

Makale Geliş Tarihi: 07.04.2017

Yayına Kabul Tarihi: 05.05.2017

\section{Özet}

Resim sanatının geleneksel ve Batılı anlamda geçirdiği süreçler, zihniyet değişimleri ile paralellik göstermektedir. Bu bakımdan sanat tarihi, zihniyet değişiminin estetik yansıma alanı olarak yeniden üretilebilir. Resimlerde kullanılan tekniklerden ele alınan temalara kadar pek çok unsur, toplumsal değişimi gösteren nüanslardan biri olabilir.

Resim sanatının toplumsal değişimin estetik kaydını tutan bir temsiliyetle de algılanabileceğini gösteren önemli temalardan biri de 'kadın'dır. Kadının resim sanatında ele alınma biçimi ile toplum hayatımızda edindiği yer, eş zamanlı bir değişim çizgisi üzerinde ilerler.

Bu makalede kadının resim sanatında bir tema olarak yer alışı ile toplum hayatımızda ve zihniyet tarihimizde edindiği yer arasında paralellikler kurulmaya çalışılacaktır. Yanı sıra kadının sanatta yer alma biçiminin erkek ideolojik söylemin bir parçası olup olmadığı üzerine düşünceler yürütülecektir.

Anahtar Kelimeler: Türk Sanatı, Türk Resmi, Kadın, Toplumsal Değişim, Popüler Kültür

\section{WOMAN AS CHANGE INDICATOR OF TURKISH SOCIETY LIFE AND PAINTING}

\section{Abstract}

Processes which painting had in traditional and European meaning show parallelism with mentality change due to mentality. For this reason, art history can be reproduced as esthetic reflection field of mentality change. Many elements from technics that are used in paintings to processed theme can be one of the shadings that show social change.

Woman is one of the important themes that show painting art can be recognized with also a representation kept esthetic record of sociological change. Woman's approach style in painting and acquired place in social life move on a simultaneous change line.

In this article, conducting parallelism between women's taking part in painting as a theme and place in our social life and mentality history will be tried. Additionally, ideas on whether taking part style of woman in art is a part of man ideological discourse or not will be carried.

Keywords: Turkish Art, Turkish Painting, Woman, Sociological Change, Popular Culture 


\section{Giriş}

Türk sanatının yüzyıllar öncesinden başlayan macerası -bu sanatın başlangıcından geçirdiği dönüşümlere kadar- multidisipliner yaklaşımla anlaşılabilir. Çünkü modern anlamda sanatın Türk toplumunda yer edinmesi ile Batılılaşma pratiklerinin doğrudan bağıntısı vardır. Yanı sıra edebiyatta yeni türlerin (roman gibi) ortaya çıkışı ile de paralellik gösterir. Bu nedenle resim sanatının sahneye çıkışı ve değişim hikâyesi zihinsel dönüşüm sürecinin pratiklerinden biridir ve resim tarihi ile Tük toplumunun zihniyet değişimi süreci birlikte okunabilir. Tam da bu noktada "kadın" toplumsal değişim sürecinin takip edilmesi gereken temel başlıklarından biri olur ve Türk sanatındaki değişim hikâyesinin de temsilini üstlenir.

Toplumsal anlamda yaşanan değişimlerin yansımalarını, bu yansımaların görünür hallerini mekân, siyaset, basın-yayın gibi pek çok alanın tarihsel sürecini inceleyerek görebiliriz. Bu süreçlerin bütün değişim dönemlerinde birbirini tamamlayan bütünlük içerisinde eş zamanlı bir çizgide ilerlediğini de fark edebiliriz. 'Kadın', Türk toplumunun geçirdiği değişim süreçlerinin yaşamın bütün alanlarında yansımalarını gösteren önemli bir unsuru olarak toplum tarihindeki yerini almıştır. Toplumsal değişimin yansımalarının araştırıldığı her alanda kadının yer alma biçimine dair somut verilerle karşılaşılabilir. Yani siyasetten sanata; mekândan; eğitim alanlarına kadar değişim göstergesi olarak kabul edilebilecek her alanda kadının yer alma biçimi anlamlıdır.

Kadının -Türk resminin temeli olarak kabul edilebilecek minyatürlerden başlayarak- resim sanatında var olma biçimi ile toplum içinde kendine yer bulma süreci de tarihi açıdan eş zamanlı ilerlemiştir. Minyatürlerden günümüz sanatına kadar kompozisyonlarda daima yer edinen kadının yalnızca bir tema olarak yapıtlarda işlendiğini düşünmemek gerekir. Süreç boyunca yalnızca bir tema olarak ele alınsa dahi bu temayı, kadının toplum içerisinde var olma tarihinin sanata yansıması olarak düşünmek daha doğru bir yaklaşım olacaktır. Bu yansımalar yalnızca Türk toplumu ile sanatı arasındaki uyumun ortaya çıkardığı estetik ifadeler değildir. Evrensel ölçekte de değişimi, kadın bağlamında anlatma gerçekliği vardır:

Türkiye'de Modernizm'le bağlantılı giden bir süreç bu. Dünya sanatında ise prehistorik çağlardan günümüze kadar kadın, sanatın içinde bir temsiliyet olarak sürekli var oluyor ve sanatın üsluplarına, ideolojilerine göre farklı biçimlerde değişerek bugüne geliyor. Başlangıçta ana tanrıça formunda "tapılan kadın" olarak başlıyor bu tabi. Meryem Ana da bir tapılan kadın. Çağların geçirdiği düşünsel değişimlere göre bir değişim söz konusu kadın formunun kullanımında. Rönesans'tan sonra farklılaşma başlıyor ve bu dönemden sonra da "anılan kadın" diyebileceğimiz bir 
kullanım var sanatta. Modern çağda ise, tüketim kültürünün içinde kadın imgesinin yeri çok sağlamdır. Ona da "satılan kadın" diyorum ben. Demek ki çok kabaca tarif edersek, "tapılan kadın", "anılan kadın" ve "satılan kadın" şeklinde giden bir süreç bu (Dastarlı, 2006: 18).

Tarihboyuncahertoplumsalyapılanma, yerleşikyaşama geçişten islamiyet'in kabulüne kadar bütünlüklü etkileri olan her değişim, kadının yaşam biçimini doğrudan etkilemiş ve bu etkiler resim sanatında da karşılığını bulmuştur. Bu nedenle kültürel ve sosyal anlamda yaşanan kırılmaların resim sanatına yansımalarını kronolojik olarak takip etmek gerekir.

\section{Minyatürlerde Kadın}

Pek çok kaynağa göre İslamiyet öncesi dönemlerden itibaren başlayan minyatür sanatı İslamiyet'in kabulünden sonra daha belirgin bir gelişim seyri izlemiştir. Metin Sözen, minyatür sanatının özellikle Selçuklular döneminde gelişmeye başladığını Osmanlılardan itibaren neredeyse kurumsallaştığını belirtir:

Türklerin büyük kitlelerhalinde Müslümanlığı kabul etmelerinin ardından,XI.yüzyılda Asya'dan Anadolu'ya gelmelerinden sonra; önce Selçuklu emirlerini himayesinde gelişen minyatür sanatı, daha sonra Osmanlı padişahlarının koruyuculuğunda ciddi bir önem kazanmıştır (Sözen, 1998: 118).

$A v$, şenlik, elçi kabulü, menkıbeler vb. minyatür sanatının ana konuları olarak dikkat çeker. Minyatür sanatçılarının kullandığı renklerden kendini ifade etme biçimine kadar üzerinde durduğu her ayrıntı, geleneksel yapının oluşmasına ya da devamına katkı sağlamıştır. Bu nedenle minyatür sanatının çizgileri, renkleri, gösterge dili ortak ve kalıp özellikleri olan geleneksel anlayışın görünür biçimi olarak da düşünülebilir. Osmanlı döneminde kadının gündelik yaşam içinde bir içyapı oluşturarak (kendi sınıfı içerisinde oluşturduğu yapılanma ve bu yapılanmanın ortaya çıkardığı farklı bir gündelik yaşam) yer aldığı söylenebilir. Tanzimat dönemine kadar devam eden bu alışkanlık, kadının erkeklerin dünyasında 'mahrem bir nesne'ye dönüşmesi anlamına da gelir:

Osmanlı Devleti'nin kuruluş döneminde kadınların yaşayışları eski Türk geleneklerine benziyor iken İslamiyetin etkisi dışında hem yerleşilen coğrafyanın etrafındaki kültürel kuşatma hem de saraya giren yabancı unsurlar beraberinde farklılaşmayı getirir. Bu farklılaşma sonucu olarak II. Murad zamanında, Osmanlı hükümdarlarının haremi olur. Kanuni dönemi ile birlikte de kadın tam anlamı ile "mahrem bir nesne" halini alır (Dulum, 2006: 14). 
Kadınların, geniş anlamda gündelik yaşamın içinde yer alamasa da bazı sosyal haklara sahip oldukları da eklenmelidir:

Osmanlı Devleti'nde kadınların (şehirli), toplumsal aktivitelerde bulunması hoş karşılanmaz ve hatta kimi zaman yasaklanırken ekonomik yaşama katılmasına karşı çıkılmamıştır. Osmanlı da kadın mal ve mülk sahibi olabilir, ekonomik yaşama katılabilir ve ticari faaliyetlerde bulunabilir (Dulum, 2006: 16).

Kadının minyatür sanatında anlatılma biçiminin de aslında yerleşik hale gelmiş toplumsal yapının yansımaları üzerinden temellendirilmesi gerekir. Kadın, Osmanlı toplumunda kendine yer bulduğu kadar minyatürlerde yer almıştır. Abdurrahman Deveci, Osmanlı minyatür sanatında ikincil öneme sahip kadının belli başlı beş biçimde yer aldığını belirtir:
A. Pencereden ve balkondan bakan genç kadınlar
B. Nedimeler
C. Şikâyette ve öğütte bulunan yaşlı kadınlar
D. Cariyeler
E. Hizmetçi kadınlar ${ }^{1}$

$\mathrm{Bu}$ genellemenin dışında kadınlar, minyatürlerde anne ya da işret meclislerinin nesnesi olarak betimlenme gibi istisnai kompozisyonlarda da görülmüştür. Kadınların kendi sosyal yapılanmaları içerisinde çıplak hallerinin resmedildiği de görülür.

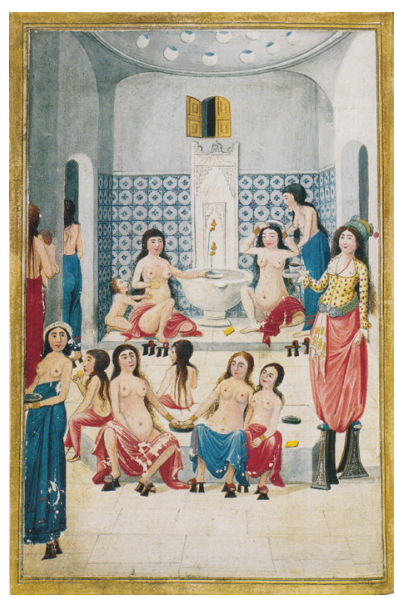

Resim I. Fazıl Enderuni Imzalı, Kadınlar Hamamı, 1750

Civarı, Minyatür, “Zenan-Name”, iÜK T 5502.

\footnotetext{
' Abdurrahman Deveci, http://www.sosyalarastirmalar.com/cilt8/sayi37_pdf/3sanattarihi_arkeoloji/ deveci_Abdurrahman.pdf, Erişim Tarihi: 01.12.2016.
} 
Kalender Paşa'nın hazırladığı I. Ahmet Albümü diye isimlendirilen murakka XVII. yüzyıl içinde hazırlanmış albümlerin öncüsü olarak kabul edilmektedir. Bu albümde, sade bir zemine yerleştirişmiş tek figürlerde giysilere, özellikle kadın giysilerinde başlıklar ve kemer, takı gibi ayrıntıların betimlenmesine özel bir önem gösterilmiştir. Ayrıca, söz konusu albümdeki müzik eşliğinde eğlenen kadınlar, maskeli gösteriler, kır sahneleri gibi tasvirler (Bağcı vd., 2006:230) artık sıra dışı ve yeni bir konu dünyasının Osmanlı resmine girdiğini gösterir. ${ }^{2}$

Terceme-i Miftah Cifrü'I Cami isimli eserin ana konusu kıyamet belirtkeleridir. Böyle kadınlı erkekli, içkili, müzikli şölen de kıyamet belirtkesi sayılmıştır. (And, 2014: 457) Dolayısıyla burada kadın kıyameti çağıran baştan çıkarıcılığıyla kompozisyonda yer alır.

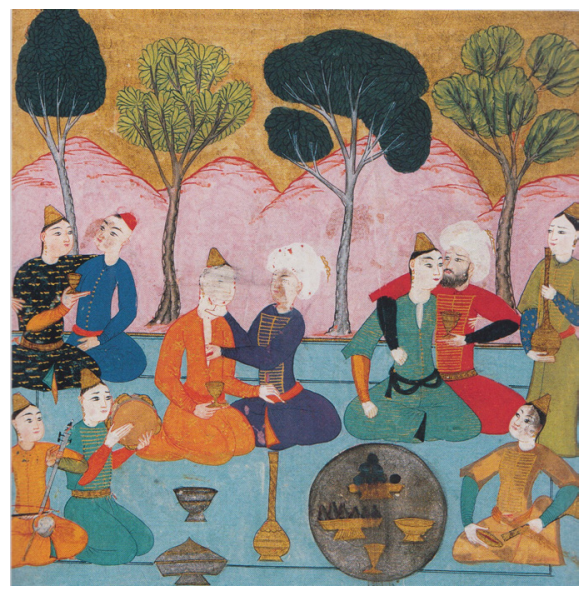

Resim 2. Nakkaş Hasan³, Erkekli Kadınlı Kır Eğlentisi, 17. Yüzyıl Civarı, Minyatür, Tercüme-i Miftâh-ı Cifru'l-Câmi, ï̈K, T6624 


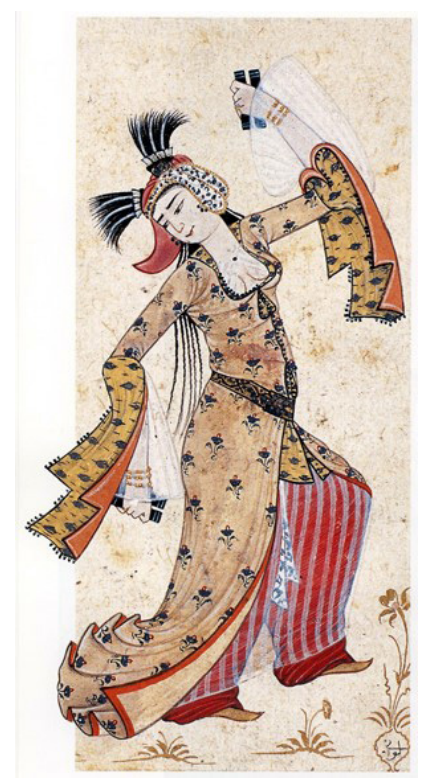

Resim 3. Levni, Dans Eden Kız, I7.Yy. Sonları, Minyatür, Topkapı Sarayı Müzesi, Ca. I7I0-20

Osmanlı toplumunda ona biçilen rol ile minyatür sanatında kadının yer alma sıkığı ve biçimi arasında organik bağlar kurulabilir. Bu nedenle minyatür sanatının bütün bir Osmanlı dünyasını hem zihinsel hem nesnel gerçeklik bağlamında resmettiği, kadının da bu resmin içinde sosyal konumlandırılma biçimine göre yer bulduğu söylenebilir.

XIX. Yüzyıla kadar Osmanlı dünyasında kadını resmeden Batılı ressamların varlığı da unutulmamalıdır. Osmanlı dünyasının Batı'da sanatsal açıdan nasıl karşılandı̆̆ını da gösteren Batı resminde kadınlar, kıyafetlerinden, aksesuarlarına kadar 'Doğu' yaşamını temsil etmiştir:

Klasik Osmanlı dönemine ait kadın imgelerini ise minyatürlerde izleyebiliriz. Öte yandan 15. Yüzyıldan itibaren çeşitli vesilelerle İstanbul'a gelen Batılı ressamların "Osmanlı"yı konu alan resimlerinde de kadın imgesine rastlanmaktadır. Bunlar ya Osmanlı giysileri içinde betimlenmiş sefir eşleridir, ya da İstanbul'da yaşayan Ermeni ve Rum ailelere mensup kadınlardır. Bazen de Batılı erkeğin hayalini kurmaktan bir türlü vazgeçemediği harem yaşantısı resmedilir (Uzunoğlu, 2008: 7).

Bilhassa Batılı seyyahların resmettiği Osmanlı kadınları, genelde Osmanlı, özelde kadın algısının Batı düşünce ve sanatında nasıl karşılandığını gözler önüne serer. Batılı ressamların Osmanlının toplumsal hayatında 
kadının yerine bakışlarında Oryantalist bir tavır olduğu gerçeği de unutulmamalıdır. Bu nedenle Batılı ressamların resimlerindeki Osmanlı kadınları, minyatürlerdeki resimlerle karşılaştıııldığında Oryantalist bakış farkı olduğunu unutmamak gerekir. Örneğin İtalyan kökenli bir aileye mensup Amadeo Preziosi, kısa süreliğine geldiği İstanbul'da hayatını kaybedene kadar yaşamıştır. Preziosi, Osmanlı kadınlarını sosyal hayatın içinde resmederken de Batılı bakışı kaybetmez.

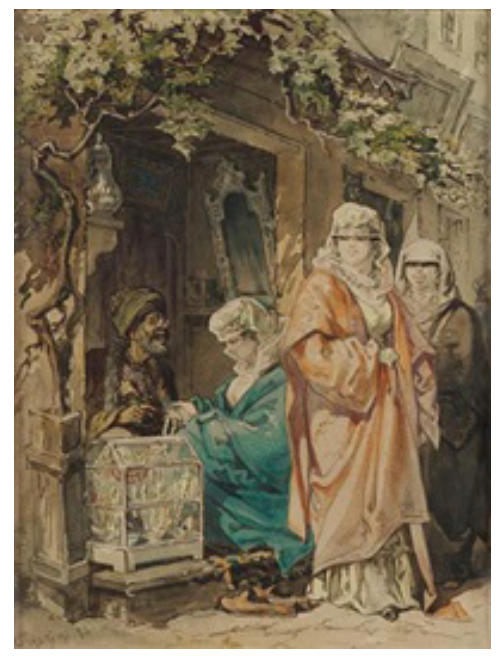

Resim 4. Amadeo Preziosi, Türk Bayanlar Mücevherat Alıyor, 1873, Suluboya, $29.8 \times 22.2 \mathrm{~cm}$.

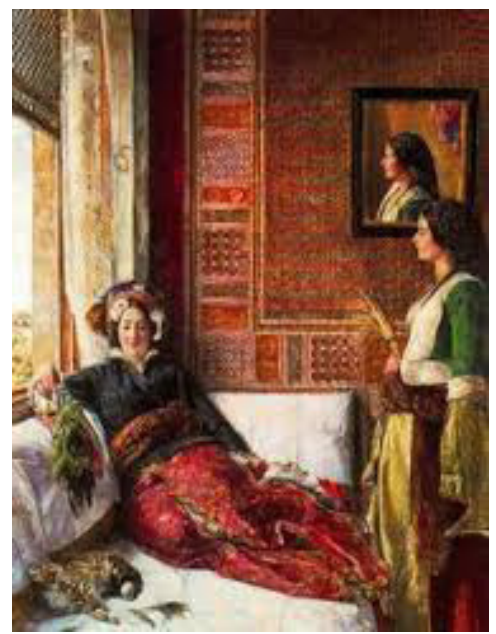

Resim 5. John Frederick Lewis, İstanbul'da Harem Hayatı, 1857, t.ü.y.b. Laing Art Gallery, B8032 


\section{Batılılaşma Dönemi Sanatında Kadın}

XIX. yüzyıl Osmanlı toplumunun eğitimden bürokrasiye, askeri alanlardan basın-yayın yaşamına kadar her alanda bir değişim sürecine girdiği dönemdir. Bu sürecin - Batı merkezli oluşu, yapısal olarak kendini bir Doğulu biçiminde konumlandıran Osmanlı toplumunda farklı anlama ve uygulama biçimleriyle karşılanmasına yol açtığı için- bazı temel sosyolojiksiyasi sıkıntılarla beraber yürüdüğ̈ görülür. Kadının toplumda ve kamusal alandaki varlığı da bu sürecin parçalarından biridir. Batılılaşma döneminde kadınlar birtakım sosyal haklara kavuşmuş olsa da yenileşme hareketinin kadına verdiği rol onun kamusal alanda serbest bir şekilde yer almasına izin verecek kadar özgürlükçü değildir:

Osmanlı'da kadının toplum içindeki yerine ilişkin tartışmalar, Tanzimat Dönemi'ndeki modernleşme çabalarıyla birlikte başlamıştır. Batılılaşma döneminde, Osmanlı'nın erkek egemen aydın sınıfı tarafından modernleşme hareketi içinde kadına bir takım görevler biçilmiştir. Bu dönemde kadınların eğitimi ve kadın hakları konusunda çeşitli düzenlemelere gidilmiş, kadınlar çalışma hayatında ve sosyal hayatta daha etkin bir biçimde yer almaya başlamışlardır (Erişti, 2015: 59).

28 Çelebi Mehmet ile başlayan bu süreç, Osmanlı toplumsal yapısı kadar sanatını da etkilemiştir. Türk sanatının Batılılaşma sürecine çabuk tepkiler verdiği söylenebilir. Bu tepkiler, sanatın her alanında görülmüş özellikle aynı zamanda aydın kimliği taşıyan yazar ve şairler, edebiyatın ön planda olduğu bir sanat ortamı yaratmışlardır. Türk resim sanatı da Batılı tarzda resim örneklerini aynı yüzyılda vermeye başlayarak sürece dâhil olmuştur:

19. yüzyılın başlarında Osmanlı'da, Batı etkisindeki resim sanatının ilk örneklerini, Batı'da resim eğitimi gören ya da yurtdışına çıkmamış ancak askeri okullarda yetişmiş olan asker ressamlar kuşağı vermiştir. Asker ressamlar olarak anılan kuşaklar, 19. yüzyıl boyunca bu alanda etkinliklerini sürdürmüşlerdir. Askeri ve sivil okullardaki resim derslerinin dışında, İstanbul'daki yabancı ressamlar da atölyelerinde resim dersleri vermişlerdir (Tansuğ, 2008: 64).

Avrupa'da sanat eğitimi alan ressamların da gelişi ile Türk resim sanatı bütünlüklü bir değişim hamlesini başlatmış olur. Kadınların resimde kendine yer bulma biçiminin de bu değişim sürecine verilen tepkiler bağlamında olduğu söylenebilir. Batılılaşma dönemi resim sanatında kadının iki önemli bağlam sayesinde kendine yer bulduğu görülür:

1. Batılı anlamda resim sanatının yerleşmeye başlaması.

2. Tanzimat'la birlikte toplum içinde gündelik yaşamın içinde tam anlamıyla yer edinememiş olsa da eğitim alma, mirastan yararlanma gibi bazı sosyal 
haklara kavuşması resim sanatında ele alınma biçimini de değiştirmiştir.

Değişime çabuk tepki veren Türk sanatı, kadını da toplumsal yaşamdan, politik düzenlemelerden önce kendi kompozisyonuna yerleştirmiştir. Osmanlı bünyesindeki azınlık sanatçıları, yenileşme sürecinden önce de Batılı tarzda resimler yapmıştır. Kendi sosyal yapılanmalarına paralel biçimde kadınları resimlerinde ön plana çıkarabilmişler hatta Batılılaşma hareketleri ile birlikte nü resimler bile yapmışlardır. Azınlık sanatçılarının bu uygulamalarından haberdar olmaması mümkün olmayan Osmanlı ressamları, Avrupa'da aldıkları eğitimin de etkisiyle kadınları resimlerine yerleştirmeye başlamışlardır. Tanzimat ve sonrasında Osman Hamdi Bey başta olmak üzere pek çok ressam kadınları gerek sosyal yaşamın gerekse yaşanan değişimin bir parçası olarak resmetmiştir:

Kadının toplum içindeki yeri, Tanzimat dönemi ile başlayan ilk modernleşme çabalarıyla, yani toplumsal modeline yönelişle birlikte tartışılmaya başlanmıştır. Batılılaşma döneminde, kadına Türk modernleşmesinde önemli roller verilmiş bir yandan da bu rolün sınırları yine erkekler tarafından belirlenmiştir (Kantar, 2007: 78).

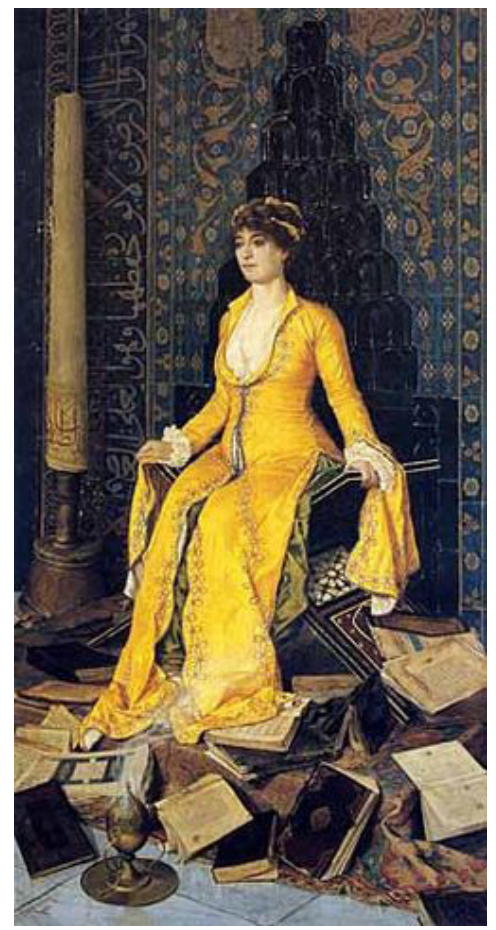

Resim 6. Osman Hamdi Bey, Mihrab (Tekvin veya Yaradılış), 1901, t.ü.y.b. , $210 \times 108 \mathrm{~cm}$. 


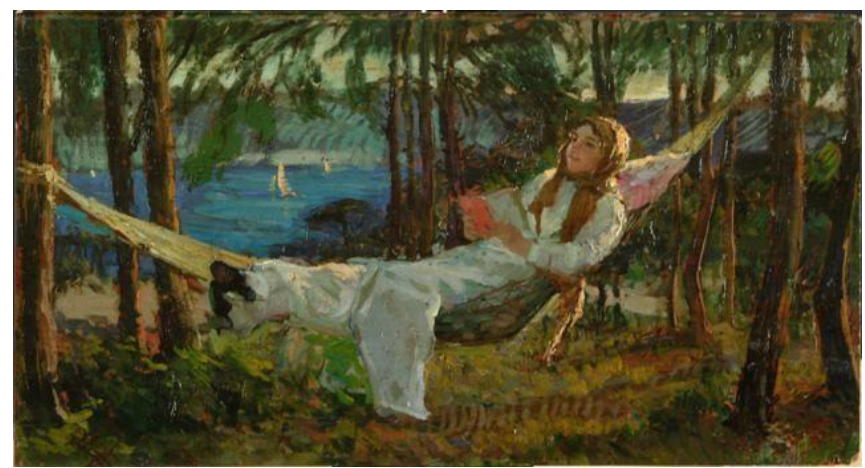

Resim 7. Ibrahim Çallı, Hamakta Uzanmış Kadın, 19/2, t.ü.y.b.

\section{Cumhuriyet ve Sonrası Türk Sanatında Kadın}

1923'e gelininceye kadar kadınların resimlerde Cumhuriyeti hazırlayan bir yaklaşımla yer aldığı gözlenir. İbrahim Çallı ve kuşağının ressamları kadını daha Batılı bir çizgide resmetmiştir:

1914 kuşağı olarak bilinen 'Çallı Kuşağı' na kadar desen çalışmalarında çıplak figürler yapan sanatçıların yağlıboyalarda genellikle peçeli ve başörtülü kadın figürlerin resmettikleri görülmektedir. Bu noktada sanatsal kaygılardan öte, sosyal yaşama ait kaygılardan bahsedilebilir. Fakat gerek 1914 öncesi gerekse de 1914 sonrasındaki kadın resimlerinde göze çarpan ortak özellik kadınsı zarafete yapılan vurgudur. Bu zarafet kıvrımlı duran gövde, eğik baş, yüzdeki masum ifade ve son derece nazik parmak hareketleriyle öne çıkar (Şahin, 2014: 74).

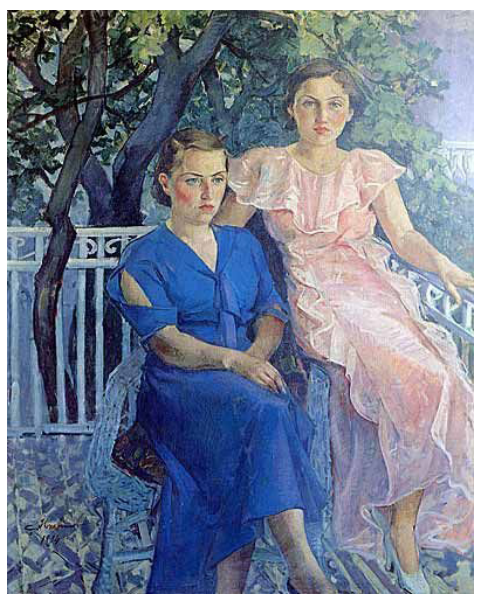

Resim 8. Ibrahim Çallı, Balkonda Oturan Kadınlar, t.ü.y.b. 
Cumhuriyetle birlikte yaşanan değişim, bu değişim sürecinde kadına verilen rol, Zeki Faik İzer'in 'İnkılab Yolunda' adlı tablosunda adeta özetlenmiştir. Bu tablo kadının Cumhuriyet'e gelinceye kadarki mücadele döneminde edindiği role vurgu yapar. Yanı sıra Cumhuriyet'le başlayan değişim programında kadının 'öncü' olarak rol alacağına da işaret eder. Resimdeki hemen her ayrıntı 'çağdaşlaşma' adıyla gömlek değiştiren değişim hareketinin ayrıntılarını verir.

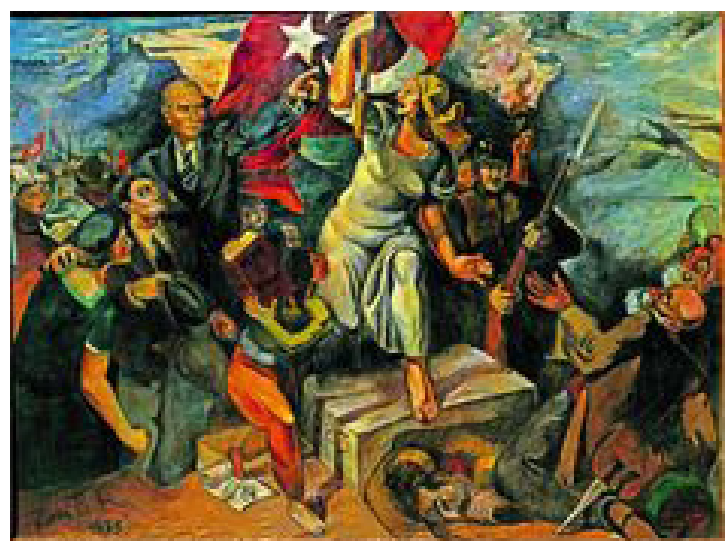

Resim 9. Zeki Faik İzer, İnkılab Yolunda,1933,t.ü.y.b. , $176 \times 237 \mathrm{~cm}$.

Bu ayrıntılardan biri de Batılılaşma hareketinin kadının varlığı ve edineceği rol üzerinden okunması gerektiğini işaret eder. Bağımsızlık ve yenilik sembolü olan bayrağı elinde taşıyan kadının ön planda olduğu resimde Mustafa Kemal'in işaret ettiği noktaya da ilerlediği görülür. Elinde Türk tarihi adlı bir kitap taşıyan kadın, aydınlanma düşüncesinin taşıyıcılarından biri olarak önlerde yer alacağını da işaret eder. Bu kompozisyon Cumhuriyet düşüncesinde kadının yeni aydın temsiliyeti ile toplum içinde yer alacağına işaret ederken Batı etkisinden uzaklaşmanın artık mümkün olmadığını da gösterir.

Mehmet Ruhi Arel'in, 1927 yılında yaptığı "Atatürk'e İstikbal" resmi de sembolik anlamlar içeren tablolardan biridir. Atatürk'ü deniz taşıtlarıyla karşılayanlar arasında en dikkat çekenlerden biri modern kıyafetleriyle geminin ucunda oturan kadındır. 


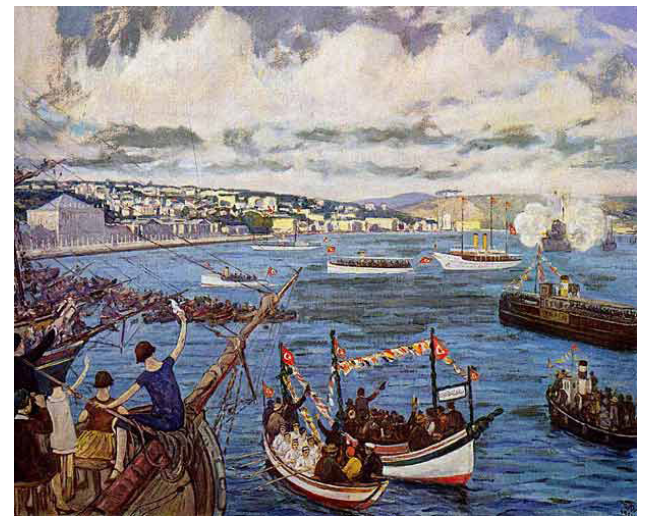

Resim 10. Mehmet Ruhi Arel, Atatürk'e Istikbal, 1927,

t.ü.y.b.

Cumhuriyet ve sonrası resimlerin alt metninde kadın, yaratılmak istenen yeni toplum düzeninin ideolojik aygıtı gibi anlatılır. 1935-1944 yılları arasında "Yurt Gezileri" adı altında Anadolu'nun farklı şehirlerine gönderilen ressamlar, kadınları zor yaşam şartlarına rağmen sağlıklı, genç, güzel, dinamik bir gövdeye sahip, kamusal alanda yer edinmiş kompozisyonlarda verirler.

1960 'tan bugüne uzanan aralıkta Modernizm'in keşfi, birey merkezli yaşam biçiminin yaygınlaşmaya başlaması gibi nedenler kadını, resim sanatında nispeten normalleştirerek anlatmış olsa da sonraki dönemlerde uygulanan beden politikaları ve hâkim popüler kültür ideolojisinin kadına farklı bir kimlik kazandırma uğraşlarını işaret eder. 1960'tan bugüne uzanan süreçte kadın; kamusal alanın, gündelik yaşamın bireyi olarak kabul gömüş olsa da bir taraftan varlığını hala devam ettiren geleneksel yaklaşımları diğer taraftan beden politikalarının, kendisini cinsel bir obje olarak sunmaya çalışan popüler kültür ideolojisinin karşısında bulmuştur. Bütün bunlar kadının erkeklerin dünyasında erkek ideolojik söylem ve onun pratiği olan yaşam alanlarının bir parçası olmaktan tam anlamıyla kurtulamadığını da gösterir. Sanatsal açıdan bakıldığında bazı sanatçıların bu bakıştan rahatsız olduğu görülebilir. Günümüzde kadının 'metalaşma'sına karşı duran ve erkek egemen söylemin sanata imgesel biçimlerde yansıdığını düşünen pek çok sanatçı sanat anlayışını bu eleştirel yaklaşım üzerinden oluşturmuştur. Bu sanatçılardan biri İpek Duben'dir.

Amerika'da siyaset bilimi ve sanat eğitimi alan İpek Duben çalışmalarında genel olarak cinsiyet, kimlik ve göç konularına eleştirel bir bakış açısıyla yaklaşmıştır. Özellikle kadının toplumda bir nesne, eğlencelik bir meta olarak görülmesini ve 
kadının kimliksizleştirmesini sorgulayan sanatçı ilk dönem yağlı boya çalışmalarında bunu açıkça ortaya koymuştur. Daha sonra sanatçıyerleştirmeleryapmaya başlayarak aynı konuları mekân gerçekliği içerisinde de sürdürmüştür (Güneş, 2013: 158).

Sanatçı, kimi zaman kendi bedenini de resminde kullanarak kadın sorunsalına vurgu yapar.

2012 serisinde, anatomik detaylarından arındırılmış, etsiz kütlelere dönüşerek motifleşen Duben'in kendi bedeni, otobiyografik referanslarından arınmış derinliksiz ve anonim bir figüre dönüşüyor. Teslimiyeti çağrıştıracak şekilde elleri göğsünde kenetlenmiş olarak tekrar eden beden imgesi, jestüel fırça darbeleriyle oluşturulmuş soyut bir arka planda, farklı zamanları bir arada barındıran "evrensel" bir özne haline geliyor. ${ }^{4}$

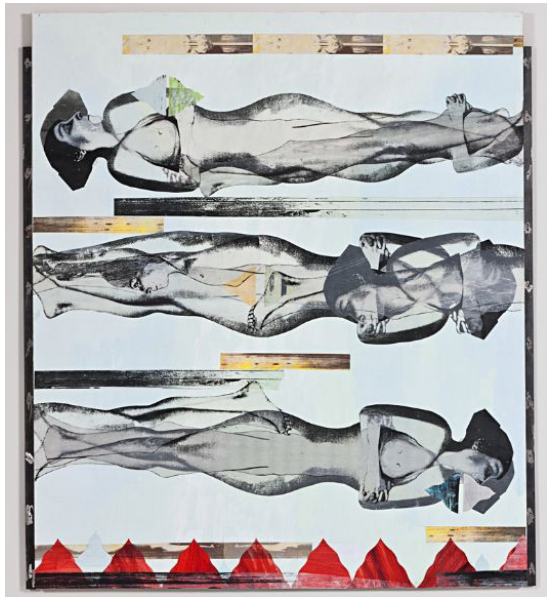

Resim II. Ipek Duben, 2012\#9, 2012, Mixed Media, $180 \times 160 \mathrm{~cm}$.

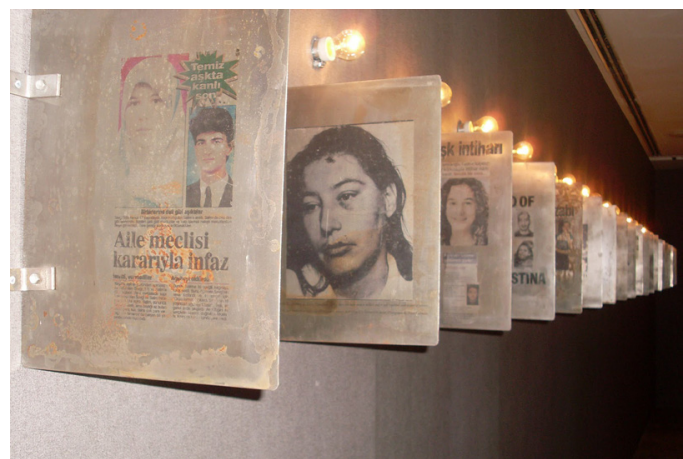

Resim 12. Ipek Duben, Aşk Kitabı, 1998-2000, Metal Plaka Üzerine Karışık Teknik, Her Plaka: 38.50×28×0,20 cm.

${ }^{4}$ http://www.haberturk.com/kultur-sanat/haber/786772-galeri-zilberman-ipek-dubeni-agirliyor, Erişim Tarihi: 03.II.2016. 
Asamblajla ortaya çıkardığı bazı yapıtlarında da sanatçı, kadının geleneksel ya da geleneksel anlayışın yanlı̧̧ yorumlanmasıyla ortaya çıkan kadın mağduriyetini eleştirir.

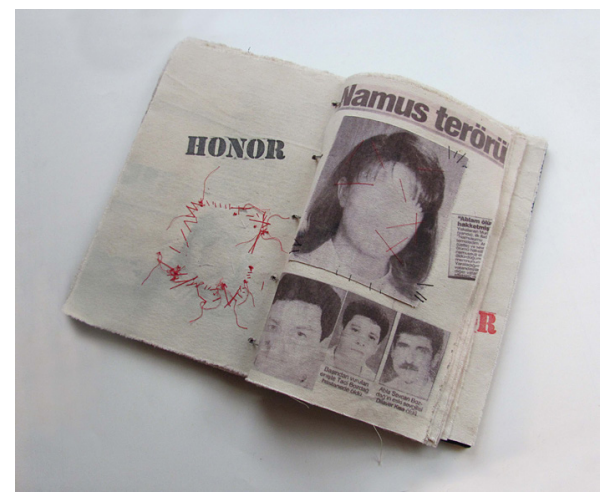

Resim 13. Ipek Duben, Namus, 2013, I3 Sayfa El Yapımı

Kitap, $33 \times 21 \mathrm{~cm}$.

İşlerini video, fotoğraf ve performans olarak da gerçekleştiren Şükran Moral, erkek egemen söylem ve geleneksel anlayışın birleşmesiyle ortaya çıkan cinsiyet politikalarının sert eleştirisini yapar. Bir sanatçı olarak Yüksekkaldırım'da bir genelevde kendisini satışa çıkardığı performansında girişe 'Çağdaş Sanat Müzesi' yazar. Bu performansını " genelev izleyicisiyle sanat izleyicisi arasındaki tek fark; genelev izleyicisi daha eğlendirici, sanat izleyicisi çoğu kez can sıkıcı." sözleriyle temellendiren sanatçının yaşamla sanat arasındaki bağ üzerinden bir cinsiyet eleştirisi yaptığı düşünülebilir. Şükran Moral'e göre sanat tarihi de bu performansının ait olduğu toplumsal yaşam ve onun tarihi gibi kadının ikincil ya da edilgen olduğu bir yapılanmadan ibarettir. Bu yaklaşım, kadının sanatta yer alma biçimine de getirilmiş sert bir eleştiridir.

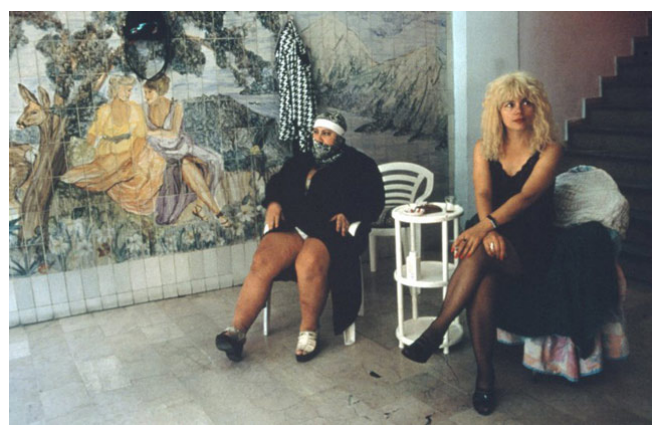

Resim 14. Şükran Moral, Genelev/Bordello,1997,Video/

Performans. 
Sanatçının en bilinen işlerinden biri olan "Speculum", Gustave Courbet'nin "Dünyanın Kökeni" adlı çalışmasına gönderme yaparak vajinayı monitörle özdeşleştirir. Bir jinekolog masasına uzanan sanatçı monitörü bacaklarının arasına yerleştirmiş ve bu monitörde dört ayrı video işi sergilenmiştir. ${ }^{5}$

'Speculum' bütün cesaretiyle kadının popüler kültür içerisinde yeniden güncellenmiş bir geleneksel algıyla karşılanma biçimine yapılan bir eleştiridir. Çünkü kadının cinsel bir obje olarak görülmesi zaten geleneksel anlamda kadına bakışın göstergelerinden biridir. Ancak kadının cinsel bir obje olarak görülmesinin ötesinde 'gösterilmesi' kadının metalaştıııldığının işaretidir. Moral, tarihsel bir algının popüler kültür ideolojisi içinde teşhire dönüşmesinden duyduğu rahatsızlığı dillendirir.

Günümüz sanatında Azade Köker, Canan Şenol, Ayden Murtezaoğlu, Füsun Onur, Hale Tenger gibi sanatçılar, kavramsal performanslarla kadının kamusal alanda daha önemlisi zihinlerdeki algılanma biçimlerine feminist bakışlarla eleştiri getirmektedirler. Bu sanatçılar arasında yer alan Canan Şenol, video işleri ile ortaya koyduğu anlayışının temeline bu sorunsalın tarihsel kökenine göndermeler yapan göstergeler de ekler. Kadının varlığının sanatsal zeminde de ikincil unsur olarak görüldüğüne dair eleştirel yaklaşımları önemser. Kadınların tarihsel süreç içerisinde ikincil unsur olarak yerleştirilmesinin yanına sanat metinlerinde kadının anlatılma biçimini de koyar. Örneğin minyatür sanatının bütün görselliğini

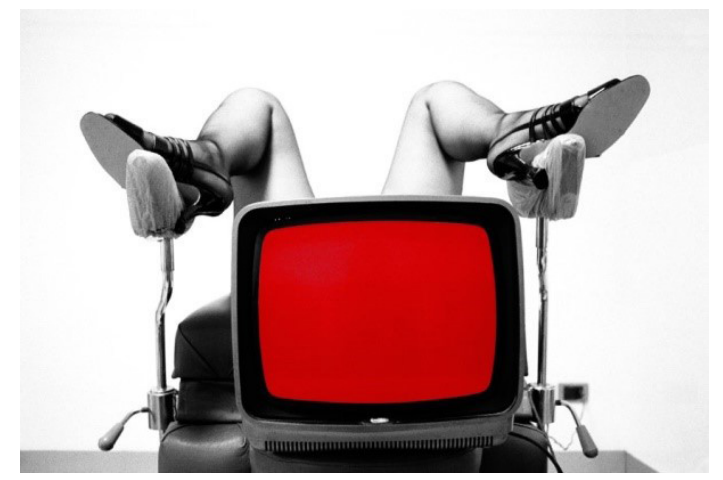

Resim 15. Şükran Moral, Speculum, 1996, "Gözün Tarihi" İsimli Performans.

video işine taşırken kadının cinsel bir obje olarak algılandığı gerçeğini, bu işin kompozisyonuna yerleştirir. Bir çeşit metinlerarası ilişki metodunu kullanarak ironik bir yaklaşım sergiler.

Sanat eleştirmenleri arasında da bu anlayışı yerleştiren erkek egemen

${ }^{5}$ Osman Odabaş, http://www.idildergisi.com/makale/pdf/I353003297.pdf, Erişim Tarihi: 02. I I.20I6. 
söylemin sanatta kullanılma biçiminden rahatsız olanlar vardır. Beral Madra'nın bir söyleşide ifade ettiği düşünceler bunun örneklerinden biridir:

Erkeklerin betimlediği kadınlara baktığımız zaman biz o kadınların öyküsünü değil o erkeklerin öyküsünü görüyoruz, sonuçta. Hatta kendi dünyalarını kadın üstünden anlatan ressamlar ve heykelcilerle karşı karşıyayız. Ayrıca, 19. yüzyılın sonuna kadar değişmeyen bir şey var; prehistorik dönemlerden bugüne gelen çıplak figür meselesi. Kadının çıplak gösterilmesidir. Artık sanat tarihinde o kadar yerleşmiş bir kanon, bir kural ki bu tamamen stereotip ve sapkınlık durumuna gelmiş, sanat tarihinde bir sapkınlık olarak görüyorum, bunu. (Dastarlı, 2006: 19)

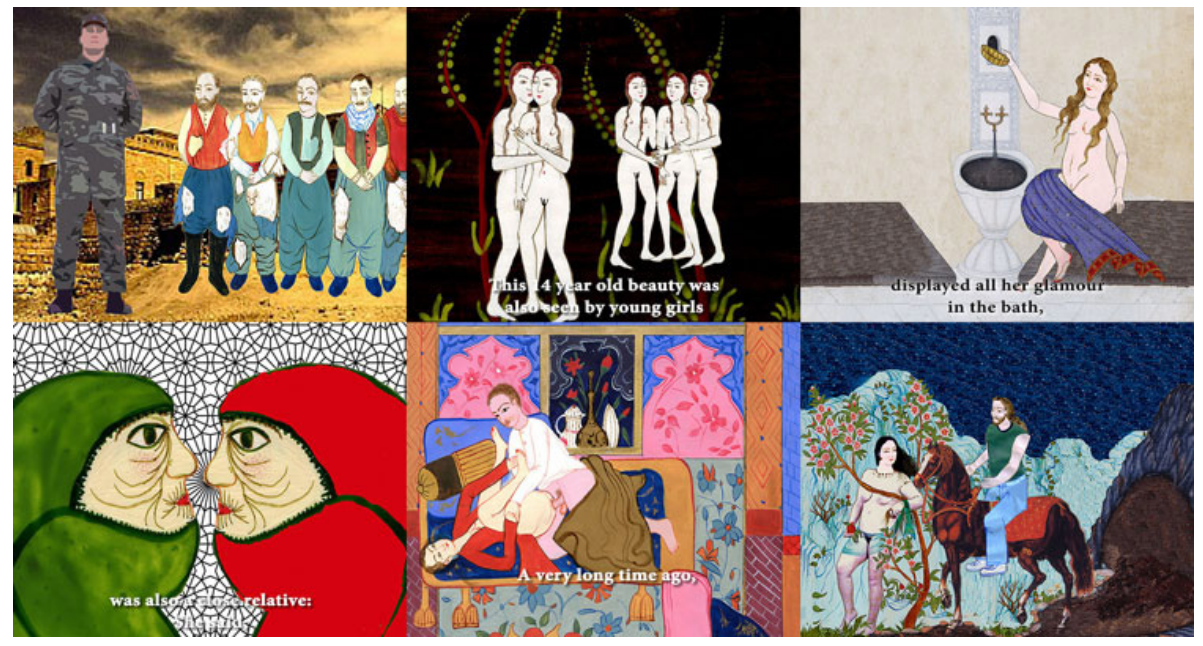

Resim I6. Canan Şenol, İbretnüma / Exemplary, 2009, Video Enstalasyon, II. Uluslararası İstanbul Bienali.

\section{Sonuç}

Türk sanatı,- her coğrafyada olduğu- gibi toplumsal değişimlerin yansıma bulduğu alanlardan biridir. Yaşanan değişimlerin öncü çıkışlarla haberciliğini üstlenmiştir de denebilir. Kadın, Türk sanatının bazen tematik bazen de imgesel biçimde toplumsal değişim süreciyle paralellik gösteren bir seyir izlediğini gösteren kesişim noktalarından biridir. Tanzimat döneminde Osman Hamdi Bey'in kadını ele alma biçimine bakılırsa Türk sanatının kadın üzerinden değişime çabuk tepki gösteren öncü tavrı kolaylıkla anlaşılabilir.

Kadının Türk sanatında ele alınma biçimi süreç boyunca önce zihinsel yapılanmada sonrasında bütün yaşam pratiklerinde erkek egemen söylemin bir imgesi biçiminde algılanmış olduğuna dair işaretler verir. Toplumsal değişim süreci ile Türk sanatının birleştiği noktada duran kadın teması ya da imgesi, kimi zaman gelenek eleştirisinin, bazen yaratılan yeni toplum 
modelinin bazen de beden politikalarının nesnesi biçiminde ele alınmıştır. Kadın minyatür sanatında ait olduğu sosyal sınıfın dışına çıkamayan bir rolle kapalı bir yapılanmanın imgesel temsilini üstlenmiştir.

Tanzimat'ta yenileşme düşüncesinin bir uzantısı olarak ortaya çıkan toplum mühendisliğinin kendisine verdiği 'aile içi eğitimci-anne' rolünün biraz daha estetize biçimde sanata yansıdığı görülür.

Cumhuriyetle başlayan değişim sürecinde başlangıçta öncü roller alsa da Modernizm sonrası dönemde farklı bir yapılandırmayla metalaştırılan kadının erkek ideolojik söylemin bir imgesi olarak sanatta yer aldığını görebiliriz. Bu görülme biçimine karşı duran bazı sanatçılar anlayışa gerek tematik gerek teknik yaklaşımlarla karşı çıkmış bütün sanat anlayışlarını bu 'karşı'lık düşüncesinden hareketle oluşturmuşlardır. 


\section{Kaynakça}

And, M. (20I4). Osmanlı Tasvir Sanatları I: Minyatür. İstanbul: Yapı Kredi Yayınları

Dastarlı, E. (2006). "Beral Madra ile Ropörtaj”, İstanbul: Rh + Sanat Dergi “Mart Sayısı”, 27.

Dulum, S. (2006). Osmanlı Devleti’nde Kadının Statüsü, Eğitimi ve Çalışma Hayatı (I8391918), Yayınlanmamış Yüksek Lisans Tezi, Osmangazi Üniversitesi Sosyal Bilimler Enstitüsü, Eskişehir.

Erişti, Ö C. (20/5). "Geç Dönem Osmanlı Resim Sanatında Kadın Imgesinin Temsili”, Moment Hacettepe Üniversitesi Illetişim Fakültesi Kültürel Çalışmalar Dergisi, 2(2), 59-79.

Güneş, N. (20/3). Resim Sanatında Kolaj, Asamblaj Ve Türk Resmine Yansımaları, Yayımlanmamış Yüksek Lisans Tezi, Trakya Üniversitesi Eğitim Bilimleri Enstitüsü, Edirne.

Kantar, S. (2007). Batılılaşma Dönemi Türk Resminde Beden Ve Temsil Sorunları Çerçevesinde Kadın Figürü, Yayımlanmamış Yüksek Lisans Tezi, Anadolu Üniversitesi Sosyal Bilimler Enstitüsü, Eskişehir.

Sözen, M. (1998). Geleneksel Türk El Sanatları. İstanbul: Hürriyet Gazetecilik ve Matbaacılık AŞ.

Şahin, M. (20/4). Çağdaş Türk Resminde Kadın Imgesi (1960 - 1980), Yayımlanmamış Yüksek Lisans Tezi, Gazi Üniversitesi Sosyal Bilimler Enstitüsü, Ankara.

Tansuğ, S. (2008). Çağdaş Türk Sanatı. İstanbul: Remzi Kitabevi.

Uzunoğlu, M. (2008). Cumhuriyetten Günümüze Toplumsal Değişimin Türk Resim Sanatında Kadın Imgesine Yansıması, Yayımlanmamış Doktora Tezi, Mimar Sinan Güzel Sanatlar Üniversitesi Sosyal Bilimler Enstitüsü, İstanbul.

\section{İnternet Kaynakları}

Internet: Dalkıran, A. http://www.idildergisi.com/makale/pdf/I354566 / 33.pdf, 03. II.2016'da alınmıştır.

Internet: Deveci, A. http://www.sosyalarastirmalar.com/cilt8/sayi37ᄀ pdf/3 sanattarihi_ arkeoloji/ deveci_Abdurrahman.pdf adresinden 0I.I2.2016 tarihinde alınmıştır.

Internet: Odabaş, O. http://www.idildergisi.com/makale/pdf/I 353003297.pdf adresinden 15.01.2017 tarihinde alınmıştır. 
Internet: http://www.haberturk.com/kultur-sanat/haber/786772-galeri-zilberman-ipekdubeni-agirliyor adresinden 03. I I.2016 tarihinde alınmıştır.

\section{Görsel Kaynakları}

Resim I. And, M. (20I4). Osmanlı Tasvir Sanatları I: Minyatür. İstanbul: Yapı Kredi Yayınları.

Resim 2. And, M. (20I4). Osmanlı Tasvir Sanatları I: Minyatür. İstanbul: Yapı Kredi Yayınları.

Resim 3. http://minyatursanati.tumblr.com/page/2

Resim 4. http://www.artnet.com/artists/count-amadeo-preziosi/turkish-ladies-buyingjewellery-neEaTioSXO5 I ppji6KQtQQ2

Resim 5. http://blog.twmuseums.org.uk/pre-raphaelite-truth-to-nature-a-watercolourby-john-frederick-lewis-3/

Resim 6. https://tr.wikipedia.org/wiki/Mihrap_(tablo)

Resim 7. https://listekitap.com/kitap/turk-ressamlarin-kitap-temali-I0-tablosu/

Resim 8. http://www.sanalmuze.org/arastirarakogrenmek/calliveismail.htm

Resim 9. https://tr.pinterest.com/pin// 7859594 / 4435 /8375/

Resim 10. http://www.tarihnotlari.com/ruhi-arel/

Resim II. http://zilbermangallery.com/20I2-el04-tr.htm

Resim 12. http://www.ipekduben.com/artist-s-books-andinstallations?lightbox $=$ dataltem-ix6rmisz

Resim 13. http://www.ipekduben.com/artist-s-books-andinstallations?lightbox $=$ dataltem-j0f4dm65

Resim 14. https://raffdergi.com/sukran-moral/

Resim 15. http://www.milliyetsanat.com/yazar-detay/ozge-yilmaz/sukran-moraluzerine//609

Resim 16. http://regardsdejanus.blog.lemonde.fr/files/2013/I I/8-ibretnuma.jpg 